\title{
Fostering Community Engagement in Protecting Coastal Zone in Malaysia
}

\author{
Yusfida Ayu Abdullah, Na'asah Nasrudin, \\ Nurul Shakila Khalid, Zafran Abidin Zafni Sham
}

Faculty of Architecture, Planning and Surveying,

Universiti Teknologi Mara (UiTM) Selangor Branch, Puncak Alam Campus, Puncak Alam 42300 Bandar Puncak Alam, Selangor,

Malaysia.

ayunazer@gmail.com, naasah76@gmail.com, nshakila89@gmail.com

\begin{abstract}
For many years now, the coastal areas in Peninsular Malaysia have been experiencing coastal erosion issues. Various initiatives were executed to reduce the coastal areas from eroding further. This study aims at assessing the local community's beliefs and insight in protecting their beaches. Pantai Jeram and Pantai Remis were selected as the case study, and a questionnaire survey using purposive sampling was conducted involving 212 residents. Site observation and a focus group discussion were also operated. Results demonstrated severe damage to the coastal areas and revealed the awareness and willingness of the community to participate in community engagement programs.
\end{abstract}

Keywords: Coastal Zone; Coastal Erosion; Coastal Management; Community Engagement

eISSN 2398-4295 (02020 The Authors. Published for AMER ABRA cE-Bs by e-International Publishing House, Ltd., UK. This is an open access article under the CC BY-NC-ND license (http://creativecommons.org/licenses/bync-nd/4.0/). Peer-review under responsibility of AMER (Association of Malaysian Environment-Behaviour Researchers), ABRA (Association of Behavioural Researchers on Asians) and cE-Bs (Centre for EnvironmentBehaviour Studies), Faculty of Architecture, Planning \& Surveying, Universiti Teknologi MARA, Malaysia. DOI: http://dx.doi.org/10.21834/ajbes.v5i18.186 


\subsection{Introduction}

Coastal zone is described as an area with a certain distance from the mainland to the continental shelf (Hail, 1980). The land area is influenced by the sea, where land is exposed to the tidal cycle. The National Coastal Zone Physical Plan (PLANMalaysia, 2012a) defines the coastal zone as covering five (5) $\mathrm{km}$ inland and three (3) nautical miles inland from the tidal area. Coastal zone has high merit in socio-economic activities and is worth protecting due to its physical setting, which suits activities including aquaculture, human settlements, eco-tourism, and shipping. However, the coastal zones are continually facing the challenges of development pressures and hazards, either from natural forces or human activities.

It cannot be denied that coastal areas offer locations for settlement because of their resources. The areas, in turn, have led to various issues like environmental pollution, landuse conflicts, and other problems (Pourebrahim, Hadipour and Mokhtar, 2015). Coastal hazards are considered as essential management issues since they had resulted in evident environmental and social catastrophes (Haslett, 2009). It is apparent that, in Malaysia, human activities such as over-logging and clear-cutting of mangroves along coastal zones had exposed the coastal areas to hazards like tidal inundation, storm surges, currents, and wave energy (Hashim et al., 2010). Van Rijn (2011) thought that coastal erosion had been intensified by human activities. This critical issue had not received much attention until the people realized that they were threatened economically, socially, and environmentally (Silva et al., 2014) and poses a significant threat to the people living along the coastlines (DelgadoFernandez et al., 2015).

The coastal zones in Malaysia have been experiencing erosion due to many reasons, particularly from human activities. Coastal erosion in Peninsular Malaysia was first addressed on a national scale more than three decades ago (Ghazali, 2006). Coastal erosion is defined as the physical wearing of surface materials by the current, wave action, and tidal currents (Azid et al., 2015). A study by Asmawi (2012) discovered that part of the root causes of coastal erosion in Malaysia includes an uncontrolled human intervention and coastal development. In another study, Van Wesenbeeck et al. (2015) agreed that one of the reasons aquaculture production collapsed was due to coastal erosion. Despite this, the seaside community is considered as an essential group, especially in the reinforcement of the country's food security (Shaffril et al., 2015)

The current policies and practices for coastal zone management may not be sustainable (Brown, 2010; Haslett, 2010). There should be a change in policy management and accepted by the local communities to ensure its effectiveness (Brown, 2010). The need for design strategies in coastal areas should be a global agenda (Lee, 2015).

Meanwhile, Asmawi (2012) claimed that the Malaysian coastal management strategies are not extensively incorporated into the land use planning system. Also, it was argued that the practice of coastal management in Malaysia is still new, and that very few town planners are conscious of this (Asmawi, 2012). To make things worse, he added that there had not been a final coastal management plan at the State level in Peninsular Malaysia except for Penang, as well as the lack of reinforcement from the State government (Asmawi, 2012). Haslett (2009) believes that the numerous agencies with various interests involved in 
managing the coast cause administrative issue hence requires one specific body encompassing of overall responsibility for management planning. Designing strategies in trying to address vulnerabilities towards hazards is often more difficult due to the physical setting and the social dimension of an area. Nevertheless, to ignore or to delay inevitably result in persistent damages to our valuable coastal ecosystems.

Previous studies demonstrated that coastal areas in Malaysia needed attention (Harbitz et al., 2016; Jensen, Savioli, and Saaban, 2016; Azid et al., 2015; Shaffril et al., 2015; Pourebrahim, Hadipour and Mokhtar, 2015; Abdullah and Qing, 2015). However, those studies focused on separate purposes, therefore producing various outcomes. Lee (2010) realized that there appeared to be a lack of public support when solving coastal issues. For that reason, this study sought to find an alternative for protecting the coastal area. In point of fact, the management and mitigation plan of the coastal area in Malaysia are known to be delivered in a conventional manner, i.e. the top-down method. Additionally, existing Malaysia's National Physical Plan for the Coastal Zone (both Volume 1 and 2), which was outlined in 2012, had not addressed the strategy for a bottom-up process (PLANMalaysia, 2012a; 2012b). Based on the continuing problems and the literature review, this study, therefore, aims at examining the local community's beliefs and perception in protecting their coastal areas.

\subsection{Literature Review}

In protecting the environment, one of the six (6) strategic thrusts in 11th Malaysian Plan 20162020 encourages to pursue green growth for sustainability and resilience (Economic Planning Unit, 2015). The government believes that "green growth should be the way of life," therefore inspiring the practice of biodiversity protection. Malaysia is committed to support and implement the 2030 Agenda for Sustainable Development. Looking at the current development strategies and goals of the country, Malaysia is on the right track towards achieving the global 2030 Sustainable Development Goals Agenda. In line with this research, New Urban Agenda (United Nations, 2016) state that cities and human settlements face unprecedented threats from unsustainable consumption and production patterns, loss of biodiversity, pressure on ecosystems, pollution, natural and human-made disasters, and climate change and its related risks, undermining the efforts to end poverty in all its forms and dimensions and to achieve sustainable development.

Based on the record issued by the Department of Irrigation and Drainage (2014) of Selangor stated that there are $71.30 \%$ of coastal areas in this state are eroded. The percentage of coastal erosion that occurred in Selangor was the third highest after Kelantan $(73.40 \%)$ and Perlis $(72.50 \%)$ based on the number of different coastal areas in their respective state. According to the National Coastal Erosion Study conducted from 1984 to 1986 stated that $29 \%$ of the total coastal area of Selangor had been eroded at various levels. In Malaysia, coastal erosion occurs due to the binding nature of the process, including waves winds, flows, and tides. Besides, it is also due to development activities along the coast, such as sea reclamation, dredging, marine mining, mangrove clearing, and structural constructions 
that disrupt the coastal dynamic.

Malaysia is the only country implementing Coastal Zone Management through the Federal system. Malaysia is driving Coastal Zone Management to make sure the environmental and natural resource plan focuses on sustaining a clean and healthy living resource approach as well as meeting the economic development needs (Mokhtar and Aziz, 2003). The Coastal Zone Management in Malaysia was established in response to problems experienced in the coastal areas such as coastal erosion, beach pollution, fisheries overexploitation, mangrove decreases.

\subsection{Methodology}

A case study method is applied when the study is intended to study a community or a small group of people (Yin, 2014). The investigation deals primarily with the site analysis and the current practice and mitigation process by the local authorities, as well as the public's inclination of involvement in coastal risk management programs.

This study is a social study that had not included any engineering or mechanical measurement of coastal erosion in the study area. It was intended to concentrate on the perceived impacts of coastal erosion through observation and did not evaluate the degree of erosion technically. Therefore, data of the decreased distance of coastal areas were not sought. The maps of coastal state from several years discussed in Section 4.2 below were obtained from Google Earth and were not anticipated for further detail analysis in terms of the magnitude and scale of erosion. This study, however, is intended to investigate the condition of the eroded and declining coastal environment of Pantai Remis and Pantai Jeram based on-site investigation and the nearby residents' beliefs and perceptions of protecting their coastal areas through Public Perception Survey. It had not included samples from outside of Mukim Jeram's areas since the purpose was to seek for possibilities of the residents in managing and protecting their coastal environment, which is why the purposive sampling was employed for the sampling frame. The study had not explored the roles and participatory approach to coastal management by other agencies or NGOs except for the Kuala Selangor District Council, the Kuala Selangor Irrigation and Drainage Department, and the Selangor Board of Water Management (commonly known as Lembaga Urus Air Selangor or LUAS).

Both Pantai Remis $\left(3.2009^{\circ} \mathrm{N}, 101.3057^{\circ}\right.$ E) and Pantai Jeram $\left(3.2253^{\circ} \mathrm{N}\right.$, $101.3057^{\circ} \mathrm{E}$ ) which are situated in Mukim Jeram, Kuala Selangor, Malaysia (Figure 1) were selected as the case study based on their long experience of coastal erosion since the 1980s. Pantai Jeram (64.23 acres) and Pantai Remis (40.21 acres) are both connected in a long stretch of coastline. Historically, during the early $80 \mathrm{~s}$, the scale of erosion was alarming, which even reached 4 meters of erosion a year.

Secondary data included current guidelines for coastal risk management in Malaysia and the mitigation plan by the Kuala Selangor local authorities. In contrast, the trends of coastal changes were captured from Google Earth from different years to examine the changes in the coastal landscape. Primary data was obtained through several techniques, namely; (1) 
Site Observation, (2) Focus Group Discussion, and (3) Perception Survey.

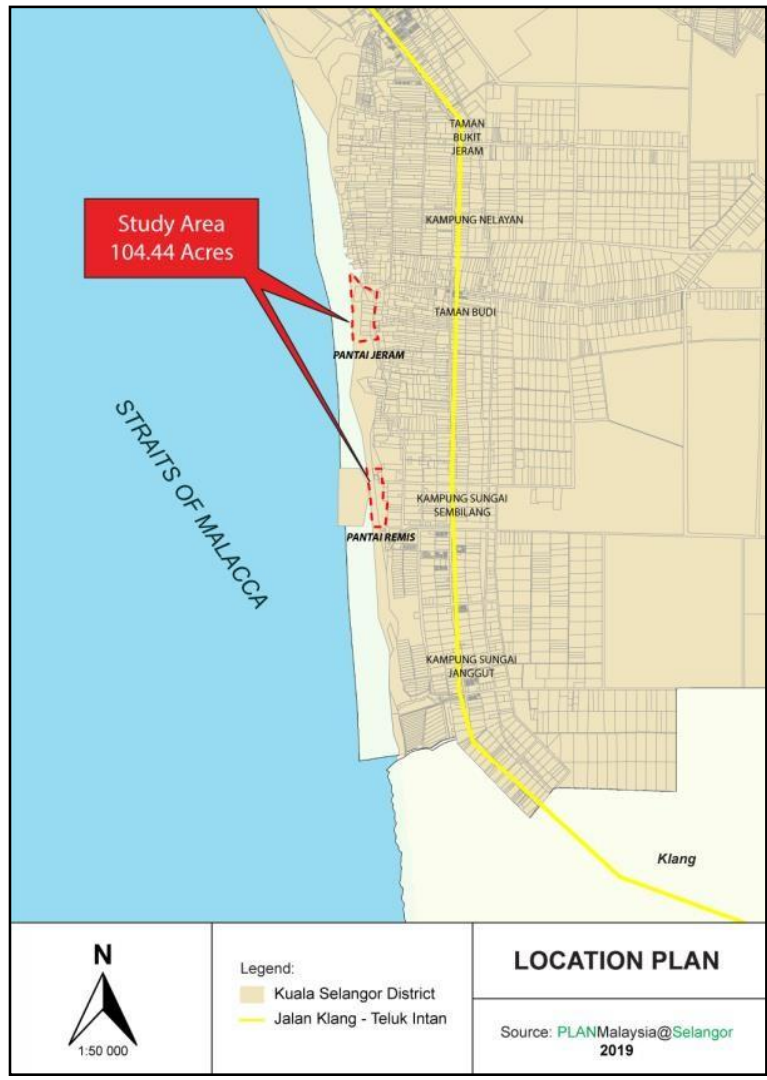

Figure 1: Location of Pantai Jeram and Pantai Remis in Kuala Selangor, Malaysia (Source: PLANMalaysia@Selangor, 2019)

A site investigation was carried out several times from 2018 to 2019 to examine the current condition of the area over time since the government progressively made recovery schemes throughout the two years. The Focus Group Discussion (FGD) was conducted on the 31 st of July 2019, involving 27 representatives from various local authorities and the local community. Participants were from the Kuala Selangor District Council, Selangor Water Management Board (known as Lembaga Urus Air Selangor or LUAS), Selangor Irrigation and Drainage Department and Kuala Selangor Irrigation and Drainage Department, and other technical departments.

The questionnaire survey (Perception Survey) was designed to examine the residents' perception and belief in protecting their coastal areas. A non-probability sampling, using the Purposive Sampling, was employed. Plowright (2011) asserted that in non-probability 
sampling, the selection of cases is based on a particular requirement, subject to the study aim, and not picked randomly. Lopez-Carresi et al. (2014) believed that the foremost people in protecting the environment from disasters are the local communities. The purposive sampling suits a smaller scale survey and is applied to gather representative samples (Bansal, 2017; Babbie, 2014). Sampling calculation suggested a total of 265 samples to represent 849 population of Pantai Remis and Pantai Jeram. However, only 212 respondents responded to the survey.

\subsection{Results}

The analysis was categorized into four parts for a better understanding of the situation in both Pantai Remis and Pantai Jeram. The most crucial step in coastal erosion management is to comprehend the current condition and the damages caused by coastal erosion. Therefore, the results were retrieved from the site observation, the trend of coastal changes, questionnaire surveys, and focus group discussion.

\subsection{Findings from Site Observation}

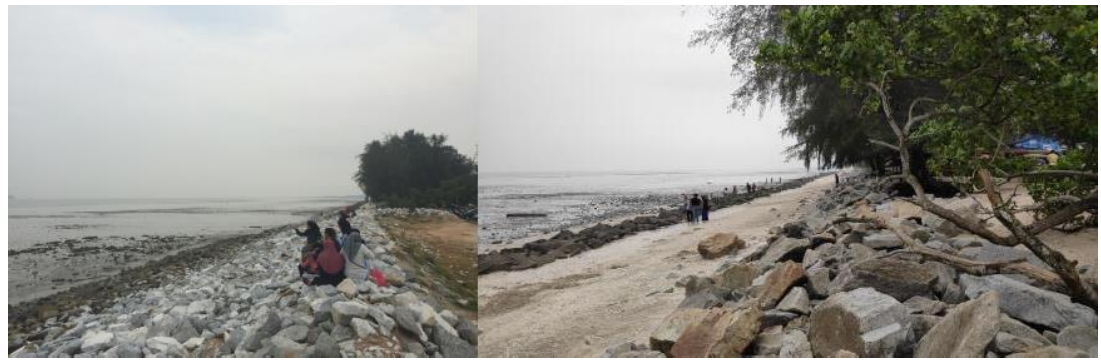

Figure 2: Images of Pantai Remis and its eroded beach in 2020

(Source: Author)

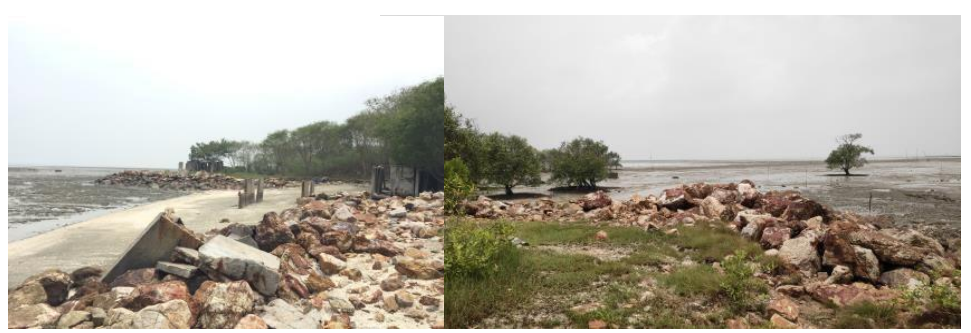

Figure 3: Images of Pantai Jeram and its current view in 2020

(Source: Author)

The coastal landscapes for both Pantai Remis and Pantai Jeram are filled with rock structure installed by the government to reduce impacts from erosion (Figure 2 and 3 ). Some parts of the beaches, especially at Pantai Remis, are not user-friendly. Visitors cannot easily reach 
the seawater since the government built a 20 -meter revetment rock along the coastline of Pantai Remis (Figures 4 and 5) and a 10-meter revetment rock for Pantai Jeram (Figure 6 and 7).

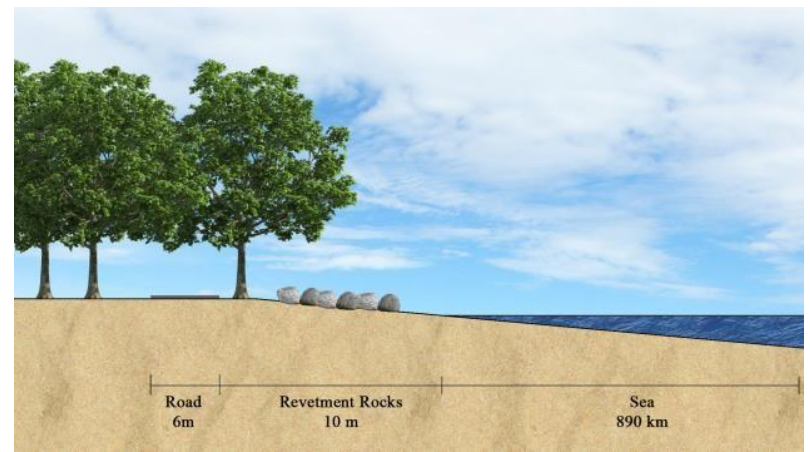

Figure 4: Cross-section of Pantai Remis

(Source: Authors' Illustration Based on Site Observation)

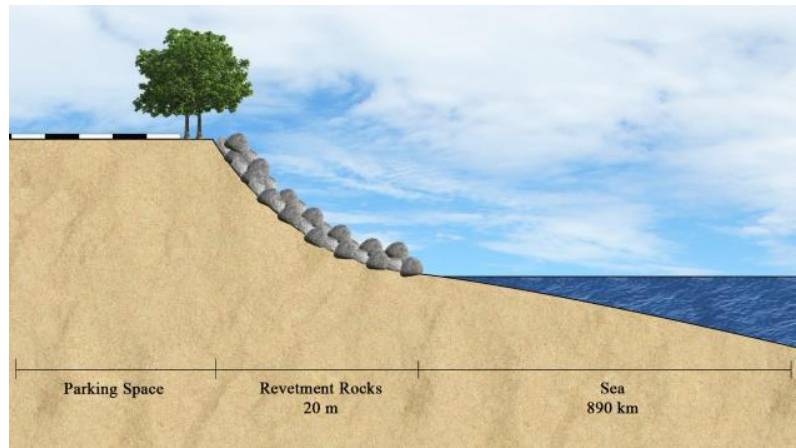

Figure 5: Cross-section of Pantai Remis at another location (Source: Authors' Illustration Based on Site Observation)

Changes in activities and coastal environment were apparent from 2018 to 2019. In 2018 when the revetment wall was built, there were not many food operators and visitors. After the completion of the project, along with newly developed public facilities like additional public toilets, upgrading of the food court, an enhancement to landscape, and upgrading of parking space, more visitors were seen, especially at the weekends. Most visitors came during the daytime in Pantai Remis for recreational purposes while Pantai Jeram draws people in the evening when the seafood restaurants are open (Figure 8). 


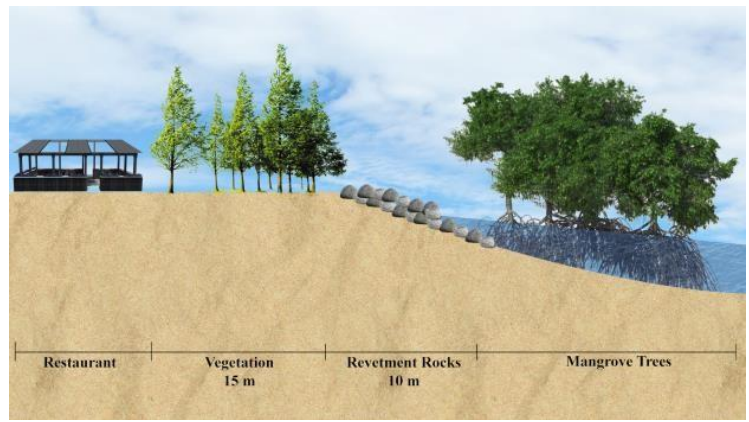

Figure 6: Cross-section of Pantai Jeram

(Source: Authors' Illustration Based on Site Observation)

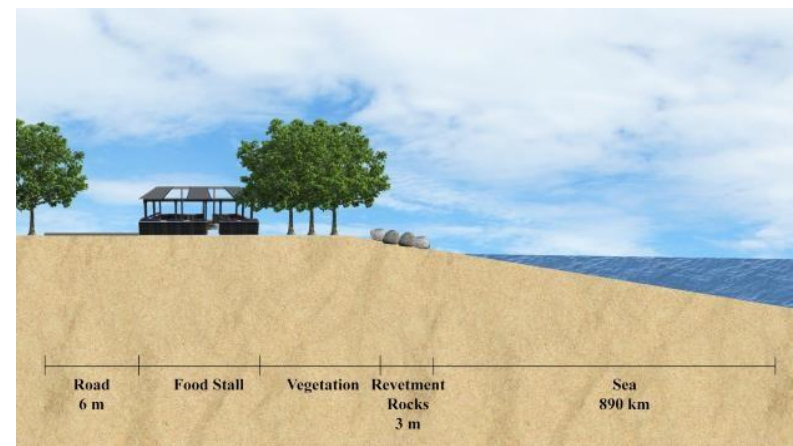

Figure 7: Cross-section of Pantai Jeram at another location

(Source: Authors' Illustration Based on Site Observation)
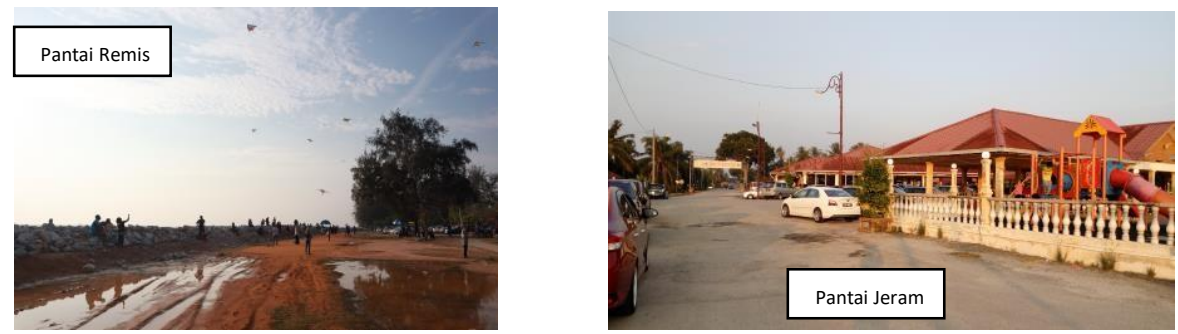

Figure 8: Activities in Pantai Remis (Playing Kites) and Pantai Jeram (Dining at Seafood

However, there were two restaurants at Pantai Remis located close to the sea line, which poses a danger to the operators and customers (Figure 9). According to PLANMalaysia (2012a; 2012b), any development along the coastline should be at a distance of at least 60 meters from the sea line. From the observation, these two restaurants are threatened by the waves and tides. Other than that, most permanent structures comply with the National Coastal Zone Physical Plan (PLANMalaysia, 2012a; 2012b) 


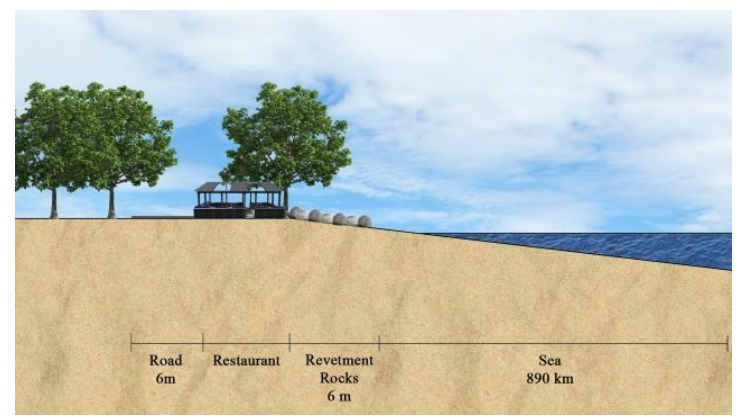

Figure 9: Cross-section of a restaurant close to the sea (Source: Authors' Illustration Based on Site Observation)

\subsection{Coastal Changes Over The Years}

Results indicated that both coastal areas had narrow beaches and landscape changed over the years. Satellite images below show the differences of the coastal view for Pantai Remis from 2010 to 2018, showing the increased width of beach probably from engineering works (Figure 10) and land use nearby also changed over the period. Changes were also apparent for Pantai Jeram, which displayed the diminishing mangroves along the coastline. In the year 2010, mangroves were seen scattered along the shore, but in 2017, mangroves were just available up north (Figure 11).

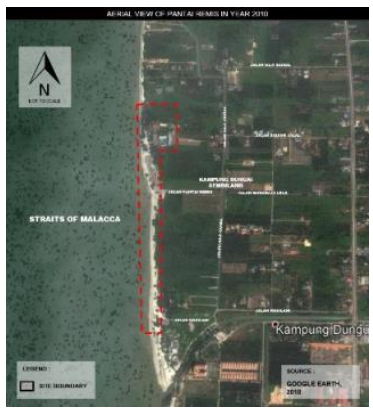

(a)

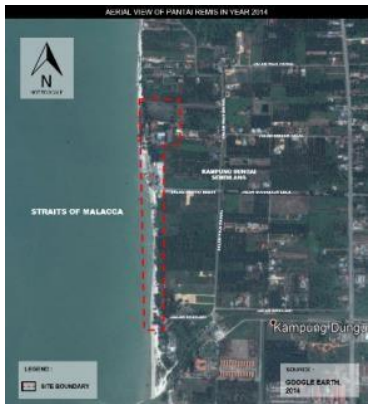

(b)

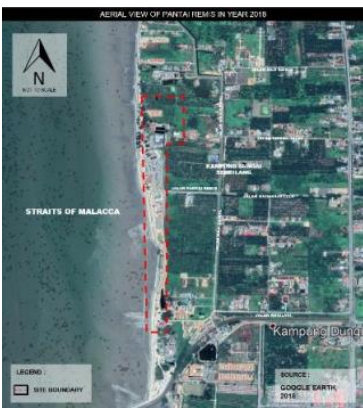

(c)

Figure 10: (a) The eroded beach in 2010; (b) Beach became even narrow in 2014; (c) Beach has improved and became wider in 2018 after the instalment of revetment rock and sand filling. (Source: Google Earth, 2010; 2014; 2018) 


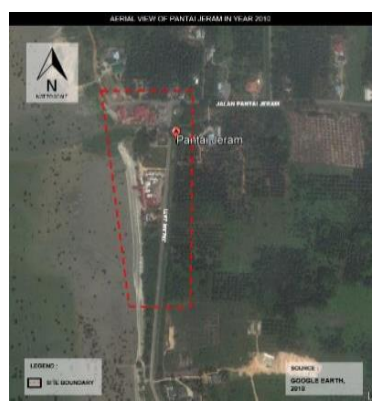

(a)

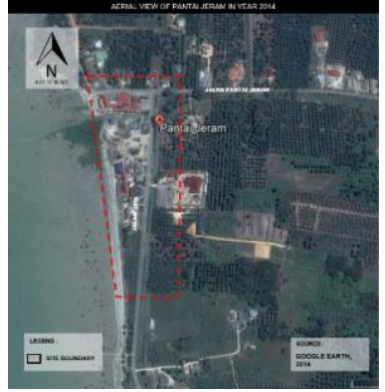

(b)

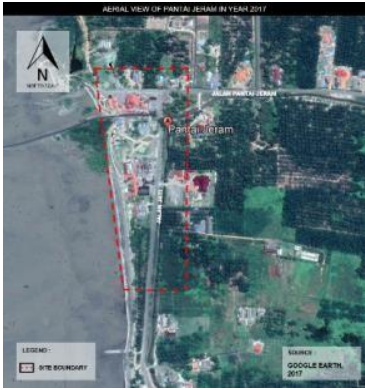

(c)

Figure 11: (a) Mangroves were seen scattered in 2010; (b) Mangroves had declined in 2014; (c) In 2017, mangroves concentrated at the north part only.

(Source: Google Earth, 2010; 2014; 2017)

\subsection{Findings from Focus Group Discussion (FGD)}

Results from the FGD indicated that there are many government agencies involved in managing and protecting the study areas. These include the Kuala Selangor District Council, Kuala Selangor Irrigation and Drainage Department, Selangor Irrigation and Drainage Department, Selangor Water Management Board (LUAS), PLANMalaysia@Selangor and other technical agencies. Each agency has its responsibilities; water pollution is under the obligation of LUAS, planning permission for development is in charge by the District Council, PLANMalaysia (2012a; 2012b) produces the guidelines for planning and development. Meanwhile, policies for development are monitored by the District Council. In short, there is no single department under one roof that manages coastal areas, but there are many agencies with various duties, and each agency looks after its part.

At present, there is no specific guideline for coastal planning for the study areas. The rules and regulations were outlined by the state and federal governments and must comply with the National Physical Plan for Coastal Zones. Since there are many socio-economic activities along the coastline, the events are monitored and controlled by the authority's enforcement unit. Planning and development must comply with the existing guidelines and should adhere to the State Structure Plan and Kuala Selangor Local Plan. Therefore, zoning demarcation is enforced.

Previously, numerous activities were carried out to create public awareness. Mangroves Planting is a yearly program, but the focus is not just for the study areas, instead of along the coastline of Kuala Selangor, which cannot guarantee that mangroves will flourish at the site. However, there beach cleaning-up programs are frequent at the site and are constantly organized by volunteers or private companies. Sometimes the District Council conducts law enforcement operations, and at times the Forestry Department helps to stop illegal shrimp farming.

A considerable sum of funding had been allocated to redevelop and maintain the coastal zones. According to the District Council, millions were spent to build the revetment rock and 
relocate local business operators, as well as upgrading the public facilities and infrastructure. Based on the FGD, the main issues of coastal risk management were the expensive recovery cost and sustaining the area to its best environmental state. Also, the residents were mentioned as part of coastal protection programs and participated in many activities like mangrove replanting, clean-up, and voluntary works.

\subsection{Findings from Questionnaire Survey}

The Perception Survey witnessed motivational responses from the local community of Pantai Remis and Pantai Jeram. The survey discovered that $90 \%$ of the total respondents are aware of the coastal erosion occurrence at their beaches. Moreover, when asked what the cause for the eroded beach was, $76 \%$ answered that the coastal erosion was caused by nature and natural process. This result informs that the local community is aware of the issue that their coastal areas are facing. In terms of interest in protecting their beaches, the majority (69\%) were willing to contribute their time and energy to participate in coastal related activities. These residents expressed their attentiveness to participate when asked whether they are eager to join any coastal protection programs.

The survey also revealed that many residents (46\%) visit their beach almost every week, and reflected their positive attention towards the shore. Furthermore, when asked why they like to repeat their visits to the areas, $46 \%$ mentioned that they are there for recreational purposes. The perception survey also saw a conflicting idea from the residents. The majority $(84 \%)$ do not want to be involved in mangrove planting but suggested that rock structure is better for coastal protection. Even so, most residents (64\%) expressed their optimistic belief that sustaining the coastal areas requires management and protection activities.

\subsection{Discussion and Recommendations}

The study indicated that Pantai Remis and Pantai Jeram are continuously facing coastal erosion since the coastal areas cannot avoid the natural occurrence of wind and waves. Both areas have long experienced coastal erosion since the early 80 s, which affected the source of income of residents and the coastal landscape. Previous studies stressed that coastal areas needed attention. Various efforts were made to reduce the severe impacts of coastal erosion. An engineering attempt was carried out in 2018 to build a long stretch of revetment rock structure along the coastline, and the project was completed in 2019. With the funding from the government, Pantai Remis and Pantai Jeram were revitalized with new facilities and enhanced recreational image. However, the installment of revetment rock had undeniably affected the landscape and the sense of natural coastal environmental scenery. Nevertheless, the areas still receive many visitors, especially at the weekends, since the coastal areas offer many recreational activities. The locals can spend their family time there since the district council allows local entrepreneurs to operate their food stalls and market, which sells local sea produce. And as expected, the people of Pantai Remis and Pantai Jeram appeared to be motivated in supporting the government's effort in managing and protecting the coastal zone. They believe that the beaches are their assets and hope to see a lasting resource that can be enjoyed by their future generation. 
Based on the results and findings of the study, several recommendations were formulated. Results indicated that there were no specific guidance for the local community to participate in any community engagement programs in managing and protecting the coastal zones. Most recovery schemes and initiatives were customarily the government's tasks carried out by the local authorities and related agencies to coastal management. This conventional approach needs to change. Previous programs and coastal protection events were carried out by the government and non-governmental agencies but not as a timescheduled basis. Programs were delivered according to the availability of funding, and most are voluntary efforts. Also, the coastal erosion events at the sites are naturally caused by winds, tides, and waves. Because of this, coastal risk management should be a continuous process but grounded by the findings from the public opinions' survey.

There were two (2) outputs from this study (Figure 12), both published in January 2020. The first output was a guidebook called the Guiding Principles (ISBN 978-967-2340-09-6) specifically designed for the local authority as a reference to manage and protect the coastal areas of Pantai Jeram and Pantai Remis. The book is the first-ever guidebook for Pantai Jeram and Pantai Remis, which can also be a reference to LUAS and the Kuala Selangor Irrigation and Drainage Department. The handbook contains a brief background of the past and current situation of the areas, and trends of coastal erosion. It also informs about the findings from the residents' opinions and beliefs about protecting their coastal areas, which value their beaches and their environment. The most crucial section in the guidebook is suggestions of principles to coastal risk management and protection, which proposes and describes six (6) general principles for practice.

The second research output was a Toolkit (ISBN 978-967-2340-10-2) for the local people of Pantai Jeram and Pantai Remis, which acts as a manual for community engagement. The toolkit is the first booklet for community engagement in Pantai Remis and Pantai Jeram being produced. The book is designed in the Malay language for more accessible knowledgetransfer to the local community. The toolkit is a short manual intended to accommodate the local community in assisting the local authority in the practice of managing and protecting their coastal areas. This booklet also informs about the background and current situation of Pantai Remis and Pantai Jeram. It conveys the knowledge of Sustainable Development Goals (SDGs) and the importance of protecting the coastal zone and imparts about coastal erosion in the study area. Even though it is a simple guide for the residents, it is furnished with suggestions of various programs for public participation. Additionally, the toolkit suggests that the local community empowers their community to organize their programs, which they can claim ownership of the initiatives. Through the proposed Beach Entity or committee, they can plan and schedule their applications using a yearly calendar that they created. The budget for programs was not specified, but the residents can seek capital or subsidy from thegovernment of NGOs since many environmental-oriented organizations exist in Malaysia, including within the State of Selangor.

This study had therefore proposed several general recommendations following the results of the study; (1) Short-term (immediate) actions; and (2) Long-term (continuous) efforts. The first category recommends urgent actions based on the condition of the study 
area. The second category requires a constant operation, which may help to sustain the coastline.

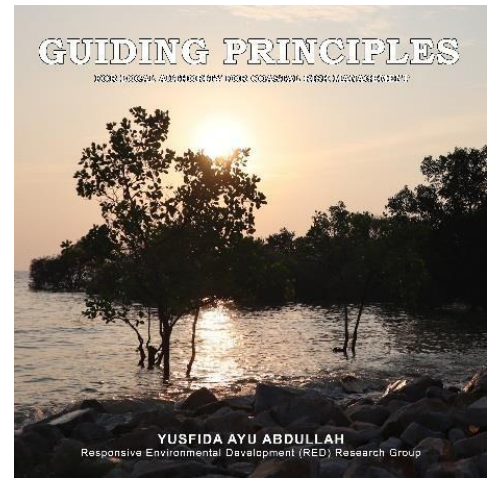

(a)

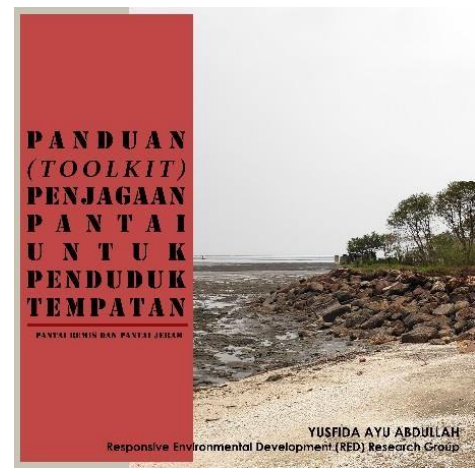

(b)

Figure 12. (a) The cover of the Guiding Principles for local authorities; (b) The cover of the Toolkit for Community Engagement

Short-term actions include a relocation program of two restaurants situated along the beach. These two shops operate daily and are threatened by the wave and high tide. To comply with the federal guideline of development along the coastline, these shops must be reallocated further from the sea line (to meet the $60 \mathrm{~m}$ distance guided by the PLANMalaysia's guidance). This action will ensure the safety of food operators, visitors, and the structure of the beach. However, this action will not stop coastal erosion since natural forces cause erosion, but it will ensure the safety of the operator and customers. The other suggestion is to organize timely-scheduled replanting and maintenance of mangroves and casuarina along the beaches, especially for Pantai Jeram. This program should be arranged at least twice a year because not all mangroves or casuarinas can hold the soil and continue to grow. Nevertheless, this requires efforts, funding, and contributions from stakeholders or government and the public.

The long-term efforts require continuous monitoring and measurement of coastal erosion. It may need engineering or technology to evaluate, capture, and record the trends. Systematic documentation will help future coastal risk management. Continuous effort in creating awareness of coastal protection among the public can be delivered through various public programs. Campaigns can be carried at public spaces or schools, and children are educated at school. At the same time, adults can be continuously reminded at their gathering locations, for example, at worship buildings during their religious events, or through the dissemination of information like pamphlets or brochures. Coastal Fair can be organized every year, which can attract more visitors, thus resulting in income to the business operators. The study also suggests a new guideline to coastal risk management for Kuala Selangor District Council to suit the local context and fit its local culture and lifestyle. The authorities could improve their practice to coastal risk management by introducing community 
engagement initiatives rigorously for the areas. The authorities had put great efforts into saving the coastal areas but had not tried to include the public into decision-making. Through this study, it was captured that the beliefs and motivation of the residents in the events of coastal protection programs are essential too. However, there was a lack of inquiries or surveys for the residents asking for their opinions and needs.

\subsection{Conclusion}

This study highlights the coastal erosion issue in Pantai Remis and Pantai Jeram in Kuala Selangor, Malaysia. Both beaches had experienced tremendous impacts from coastal erosion since the 1980s, which affected the coastal landscape and activities of the people living nearby the area, as well as the visitors. To conclude this study, the researchers believe that it is vital to incorporate the local people into coastal protection programs since the residents value their environment and the need to preserve natural resources. The study had delivered two relevant outputs to support coastal protection in Kuala Selangor, which can be a guide to the authorities and residents of Pantai Jeram and Pantai Remis. Future studies may include the effectiveness of coastal erosion recovery schemes through engineering technology, or the effects of revetment rock structure towards the coastal activities, or scrutinize the role of NGOs, or even evaluate the effectiveness of community engagement initiatives. Finally, there is no ending to coastal protection and community engagement since the beach belongs to the people themselves. The sustainability of coastal zones relies very much on us as humans.

\section{Acknowledgement}

The authors would like to thank the Universiti Teknologi Mara (UiTM) for funding this study under the REI Grant (Project Code: 600-IRMI/MYRA 5/3/REI (004/2018). We also like to express our gratitude to the local authorities of Kuala Selangor and the residents of Pantai Jeram and Pantai Remis. A special thank you note goes to the FGD participants for their input and suggestions.

\section{References}

Abdullah, L. and Qing, S.X. (2015), Quality of Life Among Coastal Population Using Weighted Geographic Information System: A Case of Setiu Wetlands, International Journal of Information Processing and Management (IJIPM), Vol. 6, Number 4, 2015.

Asmawi, M. Z. (2012), The Future of Coastal Management Programme in Malaysia: Making the Coast Visible to Planner, Journal of the Malaysian Institute of Planners, Vol. 10 (2012), pg.125-146.

Azid, A., Che Hasnam, C.N., Juahir, H., Amran, M.A., Toriman, M.E., Kamaruddin, M.K.A., Mohd Saudi, A.S., Gasim,M.B. and Mustafa, A.D. (2015), Coastal Erosion Measurement Along Tanjung Lumpur to Cherok Paloh, Pahang During the Northeast Monsoon Season, Jurnal Teknologi, 2015, pg.27-34. 
Babbie, E (2014) The Basics of Social Research (6th edition). United States: Wadsworth Cengage Learning.

Bansal, A. (2017) Survey Sampling. Oxford: Alpha Science International Ltd.

Brown, I. (2010), Multi-Functional Assessment of Coastal Landscapes with Climate Change. In: Green, D.R. (ed.), Coastal and Marine Geospatial Technologies, Coastal Systems and Continental Margins, Vol. 13, pg.335-346.

Delgado-Fernandez, I., McBride, M., Platt, R. and Cameron, M. (2015), Sefton's Coast Vulnerability to Coastal Flooding Using DEM Data, North West Geography, Vol. 15, No. 1, 2015, pg.1-8.

Department of Irrigation and Drainage (2014), Pelan Risiko Bencana Kawasan Pantai Daerah Kuala LangatSabak Bernam, Selangor, Malaysia.

Economic Planning Unit (2015) Rancangan Malaysia ke-11 (2016-2020). In: Unit Perancang Ekonomi Jabatan Perdana Menteri. Retrieved from http://www.epu.gov.my

Ghazali, N.H.M. (2006), Coastal Erosion and Reclamation in Malaysia, Aquatic Ecosystem Health \& Management, 9 (2), pg.237-247, DOI: 10.1080/14634980600721474.

Hail, J.R. (1980) Applied Geomorphology. Oxford: Elsevier.

Google Earth (2010) Satellite Images of Pantai Remis, Kuala Selangor, Malaysia.

Google Earth (2014) Satellite Images of Pantai Remis, Kuala Selangor, Malaysia.

Google Earth (2018) Satellite Images of Pantai Remis, Kuala Selangor, Malaysia.

Google Earth (2010) Satellite Images of Pantai Jeram, Kuala Selangor, Malaysia.

Google Earth (2014) Satellite Images of Pantai Jeram, Kuala Selangor, Malaysia.

Google Earth (2017) Satellite Images of Pantai Jeram, Kuala Selangor, Malaysia.

Haslett, S.K. (2009) (2nd Edition), Coastal Systems. Routledge, Taylor \& Francis Group: London.

Hashim, R., Kamali, B., Mohd Tamin, N. and Zakaria, R. (2010), An Integrated Approach to Coastal Rehabilitation: Mangrove Restoration in Sungai Haji Dorani, Malaysia, Estuarine, Coastal and Shelf Science 86 (2010) pg.118-124.

Harbitz, C.B, Kaiser, G., Glimsdal, S., Jaedicke, C., Vafeidis, A.T., Gothlich, S.E., Hoydal, O.A., Lovholt, F. and Nadim, F. (2016), Coastal Inundation, Multi-hazard Analysis for a Construction Site in Malaysia, International Journal of Risk Assessment and Management, Vol. 19, Nos. 1-2, 2016, pg.142-164.

Jensen, J.H., Savioli, J.C. and Saaban, K. (2016), The Impact of Wave Blocking from Ship Hulls on the Stability of Tg. Piai Coastline, International Journal of Environmental Science and Development, Vol. 7, 2016.

Lee, O.A. (2010), Coastal Resort Development in Malaysia: A Review of Policy Use in the Pre-construction and Post-construction Phase, Ocean \& Coastal Management, 53 (2010), pg.439-446.

Lee, Y. (2015), Protecting the Coastline from the Effects of Climate Change: Adaptive Design for the Coastal Areas of Gangneung, Korea, Journal of Building Construction and Planning Research, 2015, 3, pg.107-115. 
Lopez-Carresi, A., Forhham, M., Wisner, B. Kelman, I. and Gaillard, JC. (2014) (Eds.) Disaster Management. International Lessons in Risk Reduction, Response and Recovery. New York: Routledge.

PLANMalaysia (2012a). The National Coastal Zone Physical Plan (Jilid 1). Department of Town and Country Planning: Kuala Lumpur.

PLANMalaysia (2012b). The National Coastal Zone Physical Plan (Jilid 2). Department of Town and Country Planning: Kuala Lumpur.

PLANMalaysia@Selangor (2019) Map of Pantai Remis and Pantai Jeram, Kuala Selangor. Selangor:

PLANMalaysia@Selangor.

Plowright, D. (2011) Using Mixed Methods: Frameworks for an Integrated Methodology. London: SAGE

Publications, Ltd.

Pourebrahim, S., Hadipour, M. and Mokhtar, M. (2015), Impact Assessment of Rapid Development on Land Use Changes in Coastal Areas; Case of Kuala Langat District, Malaysia, Environ Dev Sustain, 17, pg.10031016.

Shaffril, H.A.M., D'Silva, J.L., Kamaruddin, N. and Omar, S.Z. (2015), The Coastal Community Awareness Towards the Climate Change in Malaysia, International Journal of Climate Change Strategies and Management, Vol. 7, No. 4, 2015, pg.516-533, DOI: 10.1108/IJCCSM-07-2014-0089.

Silva, R., Martinez, M. L., Hesp, P.A., Catalan, P., Osorio, A.F., Martell, R., Fossati, M., Da Silva, G.M., Marino- Tapia, I., Pereira, P., Cienguegos, R., Klein, A. and Govaere, G. (2014), Present anf Future Challenges of Coastal Erosion in Latin America, Journal of Coastal Research, Special Issue No. 71, 2015, pg. 1-16.

Taylor, B., Sinha, G. and Ghoshal, T. (2006) Research Methodology: A Guide for Researchers in Management and Social Sciences. India: Prentice-Hall.

United Nations (2016), New Urban Agenda. Housing and Sustainable Urban Development (Habitat III). Quito: Ecuador.

Van Rijn, L.C. (2011), Coastal Erosion and Control, Ocean \& Coastal Management, 54 (2011), pg.867-887.

Van Wesenbeeck, B.K., Balke, T., Van Eijk, P., Siry, H.Y., Tonneijck, F., Rudianto, M.E. and Winterwerp, J.C. (2015), Aquaculture Induced Erosion of Tropical Coastlines Throws Coastal Communities Back into Poverty, Ocean \& Coastal Management, 116 (2015), pg.466-469.

Yin, R.K. (2014) Case Study Research. Design and Methods. London: SAGE Publications Ltd. 